\title{
The Qualifications of University Librarians, 1948 and 1933
}

Mr. Kraus is assistant librarian, Howard-Tilton Memorial Library, Tulane University.

$\mathrm{P}$ REVIOUS ARTICLES on the qualifications of university librarians have been limited to discussions of the desirable educational, professional and personal qualifications of the ideal university librarian, but little information has been compiled on the qualifications of the men who are serving as chief librarians of the larger universities of the country. ${ }^{1}$ This article deals with the academic background and previous experience of the chief librarians of the member institutions of the Association of American Universities in the United States. From an objective point of view, there may be no "ideal" university librarian among these men, but nevertheless they are administering the affairs of some of the largest university libraries of the United States.

The member institutions of the Association of American Universities provide an arbitrary but workable list of the outstanding universities of the country. ${ }^{2}$ That this selection has merit as well as logic is shown by two facts: These universities awarded 73

${ }^{1}$ Cf., Wilson, L. R. [and others]. "Essentials in the Training of University Librarians." College and Research Libraries, I:13-38, December I939; McDiarmid, E. W. "The Place of Experience in Developing College and University Librarians." Library Quarterly, 1 2:614-62, July 1942; Wilson, L. R., and Tauber, M. F. The University Library. Chicago, University of Chicago Press I 945, p.235-43.

2 The U.S. universities included in the association are Brown University, California Institute of Technology, Catholic University of America, Clark, Columbia, Cornell. Duke and Harvard Universities, State University of İowa, Johns Hopkins University, Massachusetts Inof Iowa, Johns Hopkins University, Massachusetts Inton, Stanford, Washington (St. Louis) and Yale Universities, and the Universities of California, Chicago, Illinois, Indiana, Kansas, Michigan, Minnesota, Missouri, Nebraska, North Carolina, Pennsylvania, Rochester, Texas, Virginia and Wisconsin. per cent of all doctorates conferred by American universities during the years I92930 to $1945-46,,^{3}$ and no library of less than 380,000 volumes ${ }^{4}$ is included. It is assumed that the chief librarians of these institutions are, or at least should be, among the best university librarians in the United States.

Fairly complete biographical information was available from the usual sources on $3 \mathbf{I}$ of the 32 individuals serving as chief librarians of these institutions in December I948, and for 29 librarians holding the same positions in December 1933. An analysis of the academic and professional qualifications of these men (and one woman) has been made to determine: (I) what common elements may be found in the preparation for their present positions, and (2) what changes in the qualifications of university librarians have taken place during the past 15 years. Obviously only external qualifications can be considered here. The highly important qualities of executive ability, scholarship and personality certainly cannot be subjected to tabulation.

The age of the librarians of these large universities in 1948 ranges from 34 to 69 years, with a median age of 45 . The age at the time of appointment to their present positions ranges from 34 to 56 , with a median age of 40 . Of the $3 \mathrm{I}$ librarians serving in I 948 , I 5 , or nearly 50 per cent, have earned doctorates, mainly in library science (7)

\footnotetext{
3 Based on the summary tables in American Universities and Colleges. Washington, American Council on Education, I940, Table XIII, facing p. 92. Ioid.,

1948, Table 2, facing p. 58 . R. R. Bowker Co., I948.
} 
but also in history (3), English (2), or romance languages, philosophy, or classics ( I each). Fifteen have earned master's degrees in a subject field and I I have completed library school training through the sixth-year level. Twenty-five in all have received some formal library school training; 2 I have completed at least one year of library school. Six of the libarians have been awarded honorary degrees and nine have listed election to Phi Beta Kappa among their accomplishments.

Despite recent criticism of library school curricula, the prevailing pattern of education for university librarianship appears still to be via the conventional library school route. Fourteen of the $3 \mathrm{I}$ university librarians of 1948 have pursued their studies exclusively in library school and have no degrees which indicate specialization in any other subject. Five hold the doctorate in library science, five have completed work through the sixth-year level and four have received only the fifth-year B.S. degree.

Twelve of these 3 I librarians have combinations of degrees which indicate some subject specialization as well as library school training. Their programs of study, in order of their frequency, are: the doctorate in a subject field plus one year of library school (3), the fifth-year level of library school plus a master's degree in another subject (3), and the doctorate in a subject field plus less than a year in library school, the master's degree in another field plus less than a year of library school, and the baccalaureate degree plus less than one year of library school training ( $\mathrm{I}$ each). Of the five university librarians without library school training, three have a doctorate and two have master's degrees in a subject field.

These university librarians of 1948 have served diversified periods of apprenticeship before being appointed to their present positions, including from one to nine library positions, covering periods ranging from six to 36 years (median, I 3 years), not including two appointees without previous formal library experience. Their upward progress included positions on the staffs of up to ten libraries other than the ones which they now head. Only two librarians received all of their previous experience in the libraries of which they are now the chief.

A composite listing of the positions held by the 31 university librarians previous to their present appointment shows a preponderance of university library experience. Sixty-one, or nearly one-half of the I 23 positions reported, were in university library work. Forty-nine of these positions involved the administration of one or more departments of a university library. Twenty-one of the positions reported were full-time teaching positions in subjects other than library science. Eleven positions were reported from each of the following fields: public, special and college libraries. Five positions were in the field of secondary school teaching and four teaching positions in library schools were reported. The specific titles reported most frequently were : assistant, or associate university librarian (I9), university librarian ( I6), department head in a university library (14), and college librarian (9). Only I6, or less than I5 per cent of these positions, can be identified with cataloging, classification or other technical processes.

The order in which these positions were held may be of some help in determining the existence of any pattern of advancement. A majority of these librarians advanced to their present positions after serving in two earlier positions of some responsibility in other university libraries, as shown in Tables I and II.

Although the previous experience of these librarians defies categorization into neat patterns of professional advancement, some generalizations may be drawn. That uni- 
Table I

Ultimate Positions Held by University Librarians Prior to

Their University Librarianship, 1948

\begin{tabular}{|c|c|}
\hline Title & Frequency \\
\hline 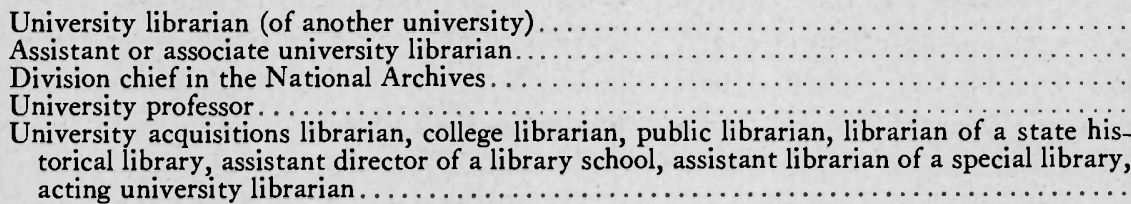 & $\begin{array}{l}\text { II } \\
8 \\
2 \\
2 \\
\text { I each }\end{array}$ \\
\hline
\end{tabular}

Table II

Penultimate Positions Held by University Librarians Prior to Their University Librarianship, 1948

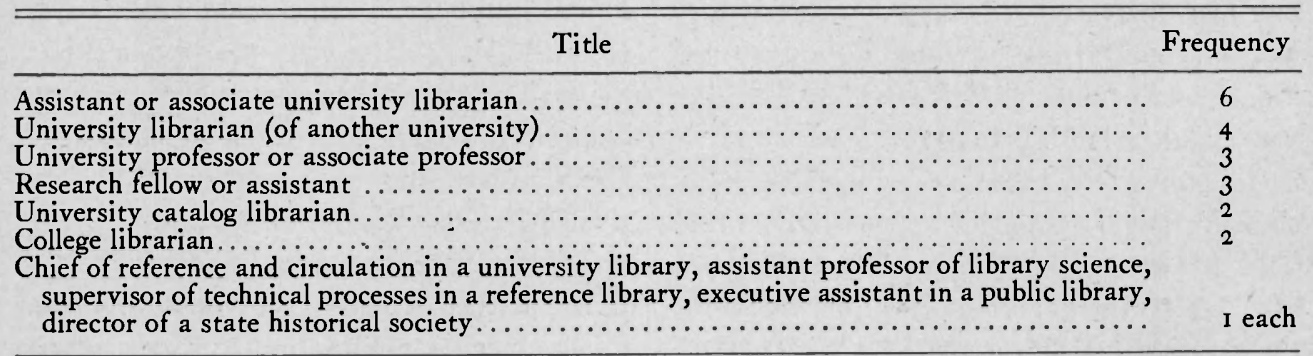

versity librarians are generally chosen from subordinate positions in other university libraries is shown by the fact that 16 of the 3I librarians have had no experience in any other type of library. Seldom, however, have subordinates been elevated to the position of chief librarian in the same library. Some teaching experience is a fairly important element in the background of university librarians as is shown by the fact that eight, or more than one-fourth of these librarians have included some full-time university teaching in their career. Public library experience has been of little importance in their backgrounds (only three librarians have served on the staff of a public library) and college library experience has been only slightly more popular, since only five librarians have received a part of their experience in college library work.

The age of the librarians serving as chief librarians of 29 of these universities in 1933 ranged from 30 to 66 years, with a median age of 57, I2 years beyond the median age of their 1948 colleagues. The age at appointment ranged from 24 to 55 , with a median age of 48,8 years beyond the 1948 median.

The abundance of degrees held by 1948 university librarians is in marked contrast to the number and variety of combinations of degrees held by the librarians of the same universities in 1933. Six of the 29 librarians about whom information is available held a doctorate; the subjects involved were classics (3), economics (I), English (I), and musicology (I). Twelve, or less than one-half, held the master's degree in a field other than library science and four had completed the equivalent of the sixth-year master's degree in library science. Four of these librarians had been awarded honorary degrees and six were members of Phi Beta Kappa.

Only 12 of the 29 had attended a library 
school, six had completed one year or more of study in library science. Four of these librarians had both a master's degree in a subject field and library school training through the sixth-year level, three held a baccalaureate degree plus less than a year of library school training, two had a baccalaureate plus one year of library school and two had a master's degree plus less than one year of study in a library school. Of the I 7 librarians who had attended no library school, six had completed studies leading to a doctorate, six held master's degrees, five had only the baccalaureate degree and one was privately educated. Clearly, library school study was by no means an indispensable part of the training for university librarianship in 1933 .

The university librarians of 1933 served a slightly longer period of apprenticeship but held fewer positions than their colleagues of 1948. The previous positions held by these university librarians of 1933 covered periods ranging from four to 39 years (median, I4 years). None of the individuals served in more than four previous positions nor in more than four libraries other than the one which he served in 1933 .

A composite listing of the positions held by the 29 librarians of these universities in I933 indicates that experience in university libraries is again the most common background. Forty-five of the 90 positions in which these librarians had served prior to their appointments as chief librarians were in university libraries; 39 of the positions involved the supervision of one or more departments. Thirteen of the 90 positions were in nonlibrary university positions, including to teaching positions and three administrative positions (college dean, college registrar, director of a university bureau of appointments). Eleven of the 90 positions were in public libraries, five in the Library of Congress, four in college libraries, three in A.L.A. war service li- brarianship and two each in special librarianship, public school teaching, state librarianship and library school teaching. The specific titles reported most frequently were: assistant, or associate university librarian ( I7), university librarian or acting librarian (II), department head in a university library (I), university professor (5), division chief in a large reference library (5), college librarian (4), university instructor (3) and A.L.A. war service (3).

Nearly one-half of the librarians considered advanced to their university librarianship from positions other than university library work as is shown in $\mathrm{T}$ ables III and IV.

Obviously there was far more cross-fertilization of experience between university librarianship and other types of library service in 1933 than in 1948. Only four of the 29 chief librarians of 1933 secured all of their experience in university libraries. Experience in public library work was a common bond in the professional advancement of nine of the university librarians, service in the Library of Congress or in one of the other large public reference libraries provided a common area for an equal number. Nine of the 29 had included some full-time teaching experience in subjects other than library science. Experience in state, special and college libraries, and in university nonlibrary administrative positions, were far more prevalent in the background of these university librarians in 1933 than in 1948 .

From a comparison of the qualifications of. the chief librarians of the institutional members of Association of American Universities in 1933 and in 1948 some definite trends are apparent. First, the post-graduate study necessary as a prerequisite for university librarianship has not only been increased but seem to be assuming some standardization. Although possession of a Ph.D. is not yet a sine qua non for the uni- 
Table III

Ultimate Positions Held by University Librarians Prior to Their

University Librarianship, I 933

Title

Frequency

Assistant or associate university librarian

University librarian (of another university).

Department chief in a university library.

Division chief in a public reference library.

Librarian of a special library.

Assistant reference librarian in the Library of Congress, assistant in a university library, director of information services for the Rockefeller Found ation

Table IV

Penultimate Positions Held by University Librarians Prior to Their University Librarianship, 1933

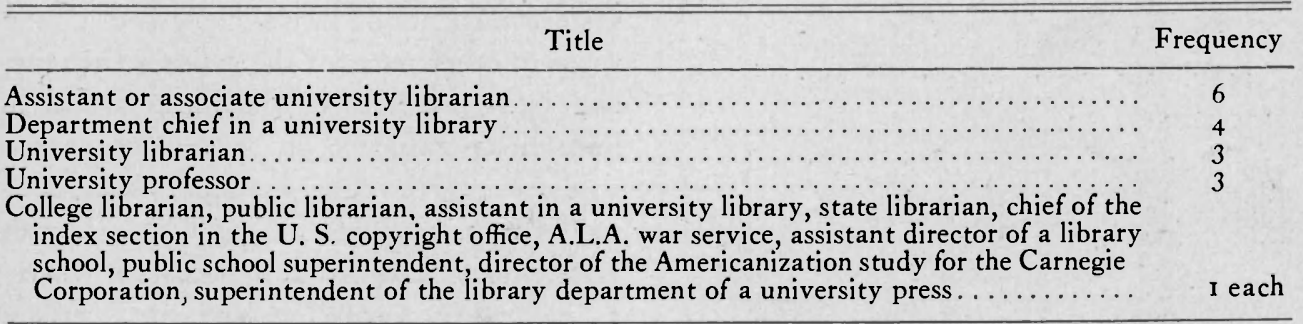

versity librarian of today, the fact that $\mathbf{2} 2$ of the 20 librarians appointed within this group during the past five years possess an earned doctorate is significant. All but one of the 20 have completed at least two years of post-graduate work.

The value of library school training seems to be fairly well established in training for university librarianship. All but five of the Association of American Universities librarians of 1948 have completed some formal study in library school as contrasted to 12 of the 29 librarians of 15 years earlier. The amount of library school training varies considerably among the 1948 university librarians, however, with seven holding a doctorate in library science, six having completed two years of library school, Io with one year and three with less than one year. An interesting innovation in academic background is shown by the four librarians who attended library school after having completed studies leading to a doctorate in another subject.

An increased mobility of university librarians is a third noticeable change in the I 948 group, in which the typical librarian served in four previous positions with an average tenure of $3 \frac{3}{4}$ years, as contrasted with the 1933 chief librarians, who typically served in three previous positions with an average tenure of $4 \frac{2}{3}$ years.

Finally, university librarianship, based on the careers of this 1948 group, shows some signs of becoming an exclusive profession with much less movement from the public, college or special library field to university librarianship than prevailed in $\mathbf{I} 933$. Whether this change is due to the specialized qualifications requisite to successful university library administration or to a certain clannishness among university librarians is a point which university librarians might well consider. 